\title{
STANDARISASI PELABELAN LARUTAN PEREAKSI DI LABORATORIUM QUALITY CONTROL MENGGUNAKAN METODE POKA YOKE UNTUK MENGHINDARI PENGGUNAAN LARUTAN KADALUARSA
}

\author{
Bella Budiani' $^{1}$, ajar Permana ${ }^{2}$, Hari Fadlisyah ${ }^{3}$ \\ Program Studi Teknik Industri ${ }^{1,2,3}$ \\ Universitas Widyatma \\ Jl. Cikutra No.204A, Bandung \\ bella.budiani@widyatama.ac.id ${ }^{1}$, permana.fajar.fp@gmail.com² ${ }^{2}$,hari.kirk10@gmail.com³
}

\begin{abstract}
Abstrak
GlaxoSmithKline (GSK) merupakan perusahaan farmasi multinasional yang berpusat di Brentford, London, Inggris. GSK memiliki departemen Quality Control (QC) yang bertanggung jawab untuk menjamin kualitas mulai dari bahan baku, bahan pengemas, dan produk jadi. Dalam kegiatan operasionalnya QC memerlukan larutan pereaksi. Penggunaan larutan pereaksi yang tidak sesuai menyebabkan hasil pengujian diragukan, sehingga kesesuaian komponen terutama tanggal kadaluarsa perlu diperhatikan. Upaya yang dilakukan untuk mencegah terjadinya penggunaan larutan pereaksi kadaluarsa dalam proses pengujian yang dilakukan departemen QC di GSK adalah menerapkan salah satu tools dari lean manufacturing yaitu Poka Yoke. Model pendekatan yang digunakan adalah control Poka Yoke. Kontrol dilakukan dengan menambahkan stiker dot berwarna pada label larutan pereaksi berdasarkan bulan kadaluarsanya.
\end{abstract}

Kata kunci :

Pelabelan, Lean Manufacturing, Poka Yoke.

\begin{abstract}
GlaxoSmithKline (GSK) is a multinational pharmaceutical company headquartered in Brentford, London, England. GSK has a Quality Control (QC) department which is responsible for ensuring the quality of raw materials, packaging materials and finished products. In its operational activities, $Q C$ requires a reagent solution. The use of the reagent solution which is not suitable causes the test results to be doubtful, so the suitability of the components, especially the expiration date, needs to be considered. The effort made to prevent the use of expired reagent solutions in the testing process carried out by the QC department at GSK is to implement one of the tools of lean manufacturing, namely Poka Yoke. The approach model used is the Poka Yoke control. Control is done by adding a colored dot sticker to the label of the reagent solution based on the month it expires.
\end{abstract}

Keywords :

Labeling, Lean Manufacturing, Poka Yoke.

\section{PENDAHULUAN}

GlaxoSmithKline (GSK) merupakan perusahaan farmasi multinasional yang berpusat di Brentford, London, Inggris. GSK di Indonesia merupakan perusahaan yang terdiri dari tiga legal entity yaitu PT Glaxo Wellcome Indonesia (PT GWI), PT SmithKline Beecham Pharmaceuticals (PT SBP), dan PT Sterling Products Indonesia (PT SPI). GSK Indonesia dipimpin oleh seorang site director yang langsung memimpin kegiatan fungsional departemen Logistik, Produksi, Engineering, EHS, dan Procurement. Dibantu oleh Head of Quality yang mengatur kegiatan manajemen kualitas dan terbagi menjadi departemen Compliance, Quality Control, dan Quality Assurance. (Budiani, 2020)

QC mempunyai tanggung jawab untuk menjamin kualitas mulai dari bahan baku, bahan pengemas, dan produk jadi. Larutan pereaksi memiliki peranan penting dalam kegiatan pengujian di QC. Penggunaan larutan pereaksi yang tidak sesuai menyebabkan hasil pengujian diragukan, sehingga kesesuaian komponen terutama tanggal kadaluarsa perlu diperhatikan. (Budiani, 2020)

Shigeo Shingo adalah pengembang Poka Yoke yang merupakan seorang engineer dari Jepang. Poka Yoke berasal dari bahasa Jepang yang artinya mistake proofing error proofing yang diterjemahkan ke bahasa Indonesia sebagai anti salah. Poka diterjemahkan sebagai kesalahan, dan yoke (yokeru) sebagai mencegah. Tujuannya adalah mencegah atau menarik perhatian orang saat kesalahan terjadi (Hudori \& Simanjuntak, 2017). Metode ini merupakan salah satu metode yang tepat yang dapat mencegah cacat yang diakibatkan oleh kesalahan manusia dalam bekerja. (Putri \& Handayani, 2019)

Penelitian ini dilakukan untuk mencegah terjadinya penggunaan larutan pereaksi yang kadaluarsa dalam proses pengujian yang dilakukan departemen QC di GSK. Kejadian tersebut biasanya terjadi akibat kecerobohan manusia atau biasa disebut human error. Kejadian tersebut dapat dicegah dengan menerapkan salah satu tools dari lean manufacturing yaitu Poka Yoke. 


\section{LANDASAN TEORI}

\section{II.1 Kualitas}

Kualitas atau mutu memiliki berbagai macam definisi atau makna, antara lain, mutu adalah keistimewaan produk yang dapat menjawab kebutuhan kocnsumen, mutu adalah sesuatu yang bebas dari cacat atau zero defect, dan mutu adalah kesesuaian dengan tujuan pengguna. Kualitas dapat dipengaruhi oleh beberapa faktor, seperti proses produksi yang merupakan prosedur dalam memproduksi suatu produk, kualitas input seperti bahan baku dan tenaga kerja, perawatan perlengkapan yang benar dan tersedianya suku cadang, dan standar kualitas yang menjadi acuan bagi perusahaan dalam menghasilkan suatu produk (Zulian, 2013).

Kualitas perlu dijamin. Terdapat beberapa cara yang dilakukan dalam menjamin kualitas, salah satunya adalah dengan melakukan inspeksi dan testing. Inspeksi merupakan suatu langkah yang dilakukan perusahaan dalam mengawasi dan menentukan kualitas input maupun output yang dihasilkan. Langkah yang dapat dilakukan dalam inspeksi antara lain adalah dengan teknik sampling yang dilakukan dengan mengambil sampel acak dari kualitas input atau output dan teknik pemeriksaan (full inspection) yang dilakukan dengan cara melakukan pemeriksaan secara lengkap dan terusmenerus dalam tiap unit proses (Zulian, 2013).

\section{II.2 Larutan Pereaksi}

Larutan pereaksi adalah larutan yang digunakan sebagai bahan untuk berlangsungnya suatu reaksi (Fauziah, 2015). Larutan standar primer merupakan larutan standar yang dibuat dari zat standar dengan kemurnian sangat tinggi yang umumnya dipasok oleh NIST, NIBCS yang dipakai untuk kalibrasi larutan standar yang dibuat. Larutan standar sekunder merupakan larutan yang konsentrasinya ditentukan dengan metode analitik yang dapat dipercaya (Darlina, 1998). Larutan pereaksi khusus adalah larutan yang digunakan untuk menguji adanya zat-zat tertentu. Contohnya pereaksi benedict untuk mengetahui adanya gula reduksi, pereaksi lugol (Iodium) untuk mengetahui adanya amilum atau sebaliknya, pereaksi Molish untuk mengetahui adanya karbohidrat, pereaksi Millon untuk mengetahui adanya protein, dan sebagainya (Fauziah, 2015).

\section{II.3 Lean Manufacturing}

Lean manufacturing merupakan suatu pendekatan sistematis untuk mengidentifikasi dan mengeliminasi pemborosan (waste) melalui serangkaian aktivitas penyempurnaan (improvement). Lean manufacturing adalah suatu pendekatan sistematis untuk mengidentifikasi dan mengeliminasi pemborosan berupa aktivitas yang tidak memberi nilai lebih (nonvalue added activities) melalui perbaikan secara terus menerus dengan mengizinkan aliran produk dengan sistem tarik (pull system) dari sudut pelanggan dengan tujuan kesempurnaan kepuasaan pelanggan (Fontana, 2011).

\section{II.4 Poka Yoke}

Poka Yoke berasal dari bahasa Jepang yang artinya adalah mencegah kesalahan yang dikarenakan oleh kecerobohan oleh tenaga manusia. Menurut konsep Poka Yoke pada dasarnya sifat manusia adalah pelupa dan cenderung untuk berbuat salah. Apalagi yang sering terjadi ditempat kerja. Pekerjalah yang sering disalahkan (Dave, 2015). Sederhananya Poka Yoke adalah menghindari kesalahan dalam produksi atau kerja. Konsep Poka Yoke ditemukan oleh Shigeo Shingo, seorang insinyur di Matsushita manufacturing dan merupakan bagian dari Toyota Production System. Poka Yoke awalnya disebut sebagai Baka Yoke, namun karena artinya kurang pantas, yaitu "menghindari ketololan", maka kemudian diubah menjadi Poka Yoke. Secara umum, Poka Yoke didefinisikan sebagai suatu konsep manajemen mutu guna menghindari kesalahan akibat kelalaian dengan cara memberikan batasan-batasan dalam pengoperasian suatu alat atau produk dan pada umumnya berkaitan dengan isu produk cacat atau defects. Shigeo Shingo memperkenalkan 3 jenis Poka Yoke (Aishwarya, 2015):

1. Metode Kontak, mengidentifikasi apakah ada kontak antara alat dan produk.

2. Metode Nilai-Tetap, memastikan apakah sejumlah tertentu gerakan telah dilakukan.

3. Metode Tahap-Gerak, memastikan apakah sejumlah langkah proses tertentu telah dilakukan.

Ada 2 model pendekatan dari Poka Yoke yaitu (Shingo, 1986):

1. Pendekatan Warning System. Istilah lain dari pendekatan ini adalah warning Poka Yoke. Pendekatan warning system adalah pendekatan yang memberikan sebuah peringatan dapat berupa lampu ataupun bunyi tertentu saat sistem mendeteksi terjadinya kesalahan.

2. Pendekatan Pencegahan. Istilah lain dari pendekatan ini adalah control Poka Yoke. Pendekatan pencegahan adalah mencegah kesalahan terjadi dan tidak memungkinkan terjadinya kesalahan, karena telah dicegah dari sistem.

Metodologi Poka Yoke terdiri dari Identify Problem, yang merupakan langkah awal dalam mengidentifikasi permasalahan dengan melakukan identifikasi proses yang berpotensi dalam menimbulkan permasalahan. Observation at Workstation, merupakan langkah setelah mengetahui sumber masalah dan masalah apa saja yang terjadi menggunakan diagram tulang ikan. Brainstorming for Idea, dilakukan dengan 
cara mengajukan masalah yang diteliti kepada pihak internal perusahaan yang terkait, kemudian mempelajari masalah tersebut dan setelahnya akan dicari rencana dan solusi perbaikan menggunakan kreatifitas pemikiran yang ada oleh beberapa pihak internal perusahaan yang berkaitan tersebut. Select Best Idea, setelah mendapatkan beberapa alternatif solusi oleh beberapa pihak internal perusahaan yang terkait, langkah selanjutnya adalah dengan memilih solusi terbaik dari semua solusi yang terkumpul. Implementation Plan and Implementation, pada tahap ini perusahaan mulai mengimplementasikan solusi terbaik yang didapat melalui perundingan yang telah dilakukan sebelumnya. Monitoring and Sign Off, merupakan langkah terakhir, langkah dimana saatnya perusahaan memonitor setiap proses produksi menggunakan perbaikan yang telah ditetapkan (Kumar, 2016).

\section{ANALISIS DAN PEMBAHASAN}

\section{III.1 Sumber dan Jenis Data}

Pengumpulan data yang dilakukan dalam penelitian ini melalui beberapa cara yaitu:

1. Observasi langsung untuk melihat cara penanganan dan pemusnahan larutan pereaksi.

2. Wawancara pada personel yang menggunakan dan menangani larutan pereaksi.

Data yang didapatkan dalam penelitian ini adalah data primer berupa gambar botol larutan pereaksi yang telah dilabeli dan gambar rak botol larutan pereaksi. Data primer tersebut ditunjukkan pada gambar 1 dan gambar 2 .

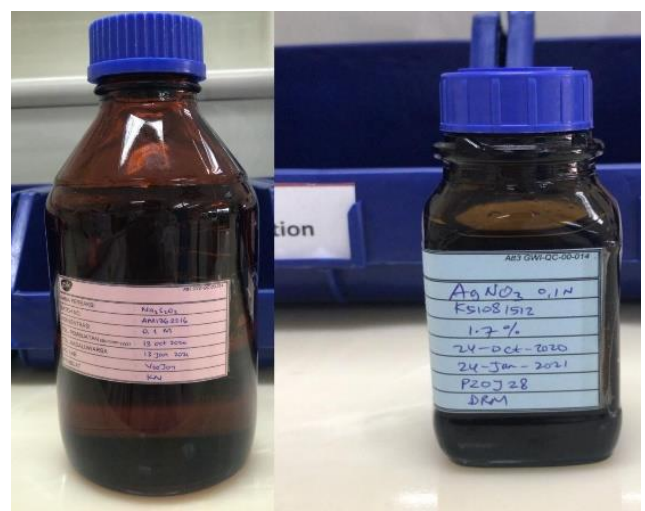

Gambar 1. Botol Larutan Pereaksi Berlabel

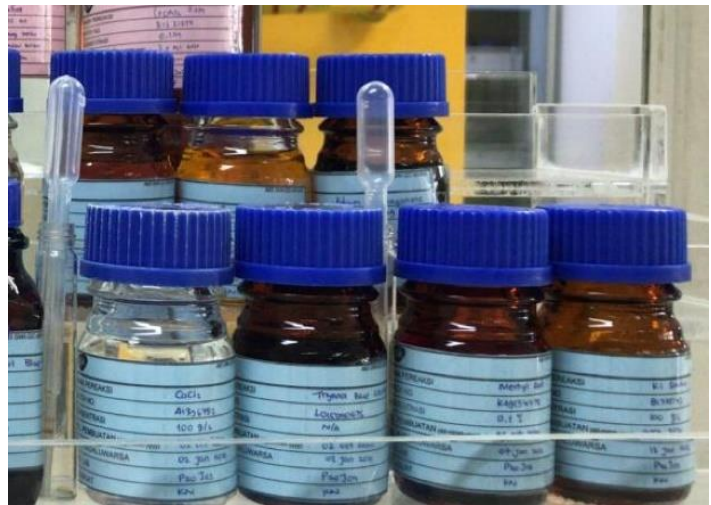

Gambar 2. Rak Botol Larutan Pereaksi

Pada gambar 1 terlihat pelabelan botol pereaksi terdapat label merah dan label biru dimana label merah untuk larutan pereaksi volumetric dan label biru untuk larutan pereaksi tambahan. Kedua label tersebut memuat poin-poin berikut:

1. Nama larutan pereaksi

2. Nomor bets larutan pereaksi

3. Konsentrasi larutan pereaksi

4. Tanggal pembuatan

5. Tanggal kadaluarsa

6. Pembuat larutan pereaksi

Larutan pereaksi tersebut disimpan dalam sebuah rak seperti yang ditunjukkan pada gambar 2, dimana seluruh larutan pereaksi disimpan pada rak tersebut. Hal tersebut memungkinkan terjadinya human error berupa kesalahan penggunaan larutan pereaksi yang sudah kadaluarsa. Menurut hasil wawancara, seharusnya larutan pereaksi yang kadaluarsa dimusnakan segera ketika memasuki masa kadaluarsanya. Hal tersebut dilakukan untuk menghindari terpakainya larutan yang sudah kadaluarsa, sehingga diperlukan sortir setiap minggunya untuk memisahkan larutan yang sudah kadaluarsa.

Kegiatan pemusnahan larutan pereaksi tersebut akan berjalan sempurna jika pemusnahan terjadi secara menyeluruh sehingga tidak menyisakan larutan pereaksi yang kadaluarsa di tak tersebut. Namun terlalu banyak faktor kesalahan dari manusia sehingga bisa saja ada larutan pereaksi yang terlewat. Sehingga larutan pereaksi yang kadaluarsa digunakan untuk pengujian, dan kualitas pengujian yang dihasilkan diragukan.

Poka Yoke dibutuhkan untuk menghindari kesalahan tersebut. Pendekatan yang dilakukan untuk penelitian ini adalah pendekatan pencegahan. Pendekatan pencegahan adalah mencegah kesalahan terjadi dan tidak memungkinkan terjadinya kesalahan, karena telah dicegah dari sistem (Shingo, 1986).

Pencegahan dilakukan dengan menstandarisasikan pelabelan larutan pereaksi dengan menambahkan stiker dot dengan warna yang berbeda-beda di setiap bulannya. Pelabelan dan 
penambahan stiker dot dilakukan saat awal pembuatan larutan pereaksi tersebut. Penambahan stiker dot mengacu pada tabel 1 berdasarkan tanggal kadaluarsa larutan yang dibuat. Sehingga larutan pereaksi yang akan kadaluarsa dapat disortir hanya dengan melihat stiker dot tersebut. Misalnya saat akan mensortir larutan pereaksi yang kadaluarsa di bulan November, dapat langsung mensortir berdasarkan stiker dot yang dikhususkan untuk bulan November. Contoh penambahan stiker dot dapat dilihat pada gambar 3 .

Tabel 1. Aturan Stiker Dot Bulan Kadaluarsa

\begin{tabular}{c}
\hline Bulan Kadaluarsa \\
Januari \\
Februari \\
Maret \\
April \\
Mei \\
Juni \\
Juli \\
November \\
Agustus
\end{tabular}

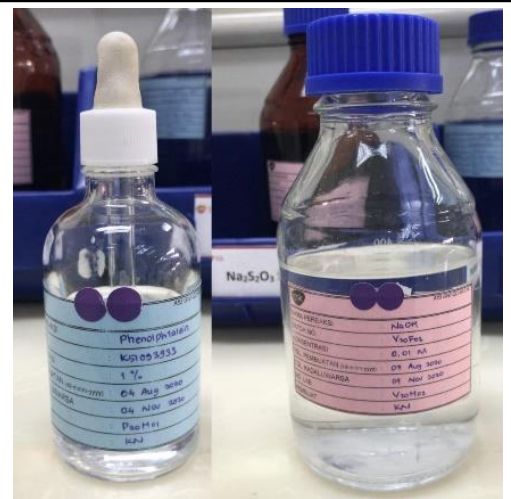

Gambar 3. Pelabelan Larutan Pereaksi dengan Penambahan Stiker Dot

Gambar 3 menunjukkan contoh larutan pereaksi yang kadaluarsa di bulan November. Larutan pereaksi tersebut di-sortir pada bulan November sehingga ketika bulan November selesai larutan tersebut sudah dimusnahkan dan tidak terpakai di bulan Desember. Jika saat ini bulan November, pengguna larutan pereaksi hanya perlu berhati-hati dengan larutan pereaksi yang berstiker dot seperti bulan November. Sehingga perlu melihat tanggal kadaluarsanya saja ketika hendak menggunakan larutan pereaksi.

\section{KESIMPULAN DAN SARAN}

Pencegahan penggunaan larutan pereaksi yang kadaluarsa dalam proses pengujian yang terjadi akibat kecerobohan manusia dapat dicegah dengan menerapkan salah satu tools dari lean manufacturing yaitu Poka Yoke. Model pendekatan yang digunakan adalah control Poka Yoke. Kontrol dilakukan dengan menambahkan stiker dot berwarna pada label larutan pereaksi berdasarkan bulan kadaluarsanya, aturan pelabelan tersebut sebagaimana yang dicantumkan pada tabel 1, sehingga pelabelan untuk larutan pereaksi diimplementasikan seperti gambar 3 .

Penelitian ini masih ada kekurangan dimana sortir hanya dapat dilakukan berdasarkan bulan kadaluarsa saja. Sehingga saran untuk perbaikan penelitian selanjutnya adalah membuat pelabelan yang dapat mensortir tanggal kadaluarsa. Saran untuk perusahaan adalah melakukan standarisasi terkait pelabelan ini untuk memudahkan pemusnahan larutan pereaksi yang kadaluarsa dan mencegah penggunaan larutan pereaksi yang kadaluarsa. Hal tersebut tentunya dapat menghindari kerugian perusahaan akibat ketidakpastian hasil pengujian di departemen QC, yang menyebabkan kualitas produk diragukan. Konsistensi dan komitmen dalam mengimplementasikan penambahan stiker dot ini oleh personel yang membuat larutan pereaksi juga sangat dibutuhkan agar perubahan ini berjalan dengan baik. 


\section{REFERENSI}

Aishwarya. (2015). poka-yoke: technique to prevent defects. International Journal of Engineering Sciences \& Research Technology, Volume: 04 Issue: 02 Feb 2015,.

Budiani, B. (2020). Tinjauan Tentang Limbah Sisa Analisa Sediaan Sirup di PT Glaxo Wellcome Indonesia. Bandung: Universitas Widyatama.

Darlina. (1998). PEMBUATAN LARUTAN STANDAR DAN PEREAKSI PEMISAH KIT RIA T3. Jurnal Radioisotop dan Radiofarmaka, Vol. I, No.2, 1998.

Dave, Y. (2015). Implementation of Poka YokeTechnique in a gear industry. Study International Journal of Latest Research in Science and Technology ISSN (Online): 2278-5299. Volume 4, Issue 3, 32-33.

Fauziah, A. (2015, May 25). Jenis jenis larutan pereaksi berdasarkan sifat larutan pereaksi yang di buat. Retrieved from slideshare: https://www.slideshare.net/atikahfauziah31/j enis-jenis-larutan-pereaksi-berdasarkansifat-larutan-pereaksi-yang-dibuat\#: :text=2.\%20Larutan\%20pereaksi $\% 2$ 0adalah\%20larutan,hidroksida $\% 20(\% 20 \mathrm{Na}$ $\mathrm{OH} \% 201 \% 20 \mathrm{M} \% 20)$.

Fontana, A. (2011). Lean Six Sigma For Manufacturing and Service Industries. Bogor: Vinchristo Publication.

Hudori, M., \& Simanjuntak, J. M. (2017). Poka Yoke untuk Pembuatan Palet Package Information di Bagian. IEJ Journal, Industrial Engineering Journal Vol.6 No.1 (2017) 1621.

Kumar, R. (2016). Poka-Yoke Technique, Methodology, \& Design. Indian Journal of Engineering, 13(33), 362-370.

Putri, D. R., \& Handayani, W. (2019). ZERO DEFECT PADA PRODUKSI KANTONG KRAFT MELALUI METODE POKA YOKE DI PT. INDUSTRI KEMASAN SEMEN GRESIK. Journal MEBIS, Journal Manajemen dan Bisnis Volume 4, Nomor 1. Juli 2019, pp. 44-58.

Shingo, S. (1986). Zero quality control: Source inspection and the. USA: CRC Press.

Zulian, Y. (2013). Manajemen Kualitas Produk \& Jasa. Yogyakarta: Ekonisia. 